OPEN ACCESS

Edited by:

Fernando A. Arosa,

University of Beira Interior, Portugal

Reviewed by:

Fabio Malavasi,

University of Turin, Italy

Heriberto Prado-Garcia,

Instituto Nacional de Enfermedades

Respiratorias, Mexico

${ }^{*}$ Correspondence:

Danay Saavedra

danays@cim.sld.cu

Specialty section: This article was submitted to

T Cell Biology,

a section of the journal

Frontiers in Immunology

Received: 03 October 2016

Accepted: 30 January 2017

Published: 14 February 2017

Citation:

Saavedra D, Garcia B and Lage A (2017) T Cell Subpopulations in Healthy Elderly and Lung Cancer

Patients: Insights from Cuban

Studies.

Front. Immunol. 8:146.

doi: 10.3389/fimmu.2017.00146

\section{T Cell Subpopulations in Healthy Elderly and Lung Cancer Patients: Insights from Cuban Studies}

\author{
Danay Saavedra*, Beatriz Garcia and Agustin Lage \\ Clinical Immunology Department, Center of Molecular Immunology, Havana, Cuba
}

The senescence of the immune system and the risk of cancer increase with aging. Age itself entails changes in the immune system, which are related to a decrease in thymic output of naïve lymphocytes, an accumulation of chronic antigenic load, notably chronic viral infections such as cytomegalovirus (CMV), and replicative senescence of lymphocytes. These changes could eventually contribute to cancer risk and affect the response to cancer treatment. However, several confounding factors make it difficult to draw a picture of causal relationships. Studies in diverse human populations could contribute to clarify these complex relationships. Here, we summarize the current knowledge about the senescence of the T cells, the relationship with CMV infection, cancer, and cancer treatment. We also review the results of a series of studies performed in Cuba whose population is characterized by the unusual combination of long life expectancy and high antigenic load, including high seroprevalence of CMV, typical of tropical countries. Although immunosenescence affects almost all components and functions of the immune response, its most salient feature is a decrease in numbers and proportions of naïve $\mathrm{CD}^{+} \mathrm{T}$ lymphocytes and an accretion of terminally differentiated $\mathrm{CD} 8^{+} \mathrm{T}$ lymphocytes. These features were confirmed by the Cuban studies, but interestingly a clear gender effect also appeared. Moreover, as aging is a global phenomenon, a fast increase in elderly with malignancies is expected; therefore, the evaluation of patient's immune status would support the decision of treating them with immunotherapy and predict the efficacy of such treatments, thereby improving benefits for the patients.

Keywords: CD8 T cells, late-stage differentiated CD8 T cells, non-small cell lung cancer, cancer vaccine, CMV

\section{INTRODUCTION}

Aging is related to changes in innate and adaptive immune system. Those age-related changes could be associated with susceptibility to infectious diseases, Alzheimer's disease, autoimmunity, osteoporosis, and cancer (1).

However, several potentially confounding factors make it difficult to draw a clear picture of causal relationships. For example, the risk of cancer increases with age and cancer itself. Cancer treatment could also influence the immune system and chronic infections such as cytomegalovirus (CMV) could drive immunosenescence. These processes occur simultaneously; nevertheless, it is not yet determined in what magnitude they are causally related (2). 
The changes most consistently found in immunosenescence studies pertain to $\mathrm{CD} 8^{+} \mathrm{T}$ cells. It is well documented that with decrease in age naïve $\mathrm{CD}^{+} \mathrm{T}$ cells, highly differentiated $\mathrm{CD} 8^{+}$ T cells lacking CD28 accumulate and those $\mathrm{CD} 8^{+} \mathrm{CD} 28^{-} \mathrm{T}$ cells upregulate the expression of CD45RA. Additionally, these cells show signs of replicative senescence such as a decreased proliferation ability, shortened telomeres, impairment of telomerase activity, and upregulation of CD57 $(3,4)$. These facts have been frequently associated with chronic CMV infection (5).

The relationship between these changes and a susceptibility to disease was first documented in the Swedish octogenarian study (OCTO-immune). This study defined the concept of "immune risk profile" (IRP). The IRP was described as a decrease in number and frequency of B cells, an increased count of $\mathrm{CD}^{+}$memory $\mathrm{T}$ cells, a CD4/CD8 ratio of less than 1 , and a rise of $\mathrm{CD} 8^{+} \mathrm{CD} 28^{-}$ among other late-stage differentiated $\mathrm{T}$ cells (6). Additionally, most of these late-stage differentiated cells express CD57 (7). The IRP was also associated with high serum concentrations of proinflammatory cytokines and seropositivity to $\operatorname{CMV}(6,8)$.

High prevalence of CMV is found worldwide; however, it fluctuates depending on the region (9). The CMV infection frequently starts during adolescence and persists throughout life. The expansion of $\mathrm{CD}^{+} \mathrm{CD} 28^{-} \mathrm{T}$ cells upregulating $\mathrm{CD} 57$ has been associated with CMV infection. It is considered one of the main causes of immunosenescence (8).

A possible connection between the high prevalence of CMV infection in tropical countries and some sociocultural behaviors, which contribute to CMV transmission in early stages of life, has been postulated (10). Our group confirmed a high seroprevalence of CMV infection in healthy Cubans from an early age (4).

In the present paper, the current knowledge on the dynamics of $\mathrm{T}$ cell subpopulations during aging is reviewed, as well as the relationship with CMV infection, cancer, and cancer treatment. The results of several studies carried out in Cuba are also interpreted. As Cuban population presents an unusual combination of a long life expectancy and high antigenic load of a tropical country, it is a kind of natural experiment, which could show novel aspects in the relationships between immunosenescence and chronic non-communicable diseases.

\section{THE INCREASED PROPORTION OF LATE-DIFFERENTIATED CD8 T CELLS IN HEALTHY CUBANS IS INFLUENCED BY AGE AND GENDER}

Long-lasting antigenic stimulation causes the progressive increase of late-stage differentiated, oligoclonal $\mathrm{T}$ cells, mainly, but not exclusively, within the $\mathrm{CD}^{+} \mathrm{T}$ cell compartment. Increasing evidence demonstrate that the $\mathrm{CD} 8^{+} \mathrm{CD} 28^{-}$and $\mathrm{CD} 8^{+} \mathrm{CD} 57^{+} \mathrm{T}$ cell populations play an essential role in innumerable diseases or chronic inflammation-related conditions, associated with chronic immune stimulation such as cancer, chronic intracellular infections, chronic pulmonary diseases, autoimmune diseases, and allogeneic transplantation (11).

Older individuals tend to exhibit abundance of late-stage differentiated memory $\mathrm{T}$ cells. CD57 is a receptor expressed on $\mathrm{CD}^{+}$and $\mathrm{CD}^{+} \mathrm{T}$ cells in late stages of differentiation (12). Late-differentiated $\mathrm{T}$ cells are characterized by the expression of CD45RO, reduced or almost undetectable expression of costimulatory molecules CD27 and CD28, and chemokine receptor CCR7. The re-expression of CD45RA is also characteristic (13).

Previous reports confirmed that $\mathrm{CD} 57^{+} \mathrm{CD} 8^{+} \mathrm{T}$ cells can be defined as "replicatively senescent cells," although these cells are not "functionally exhausted" (13). The progressive decrease of $\mathrm{T}$ cell function as a consequence of a chronically high antigen load is described as part of the phenomenon of exhaustion (14). Nevertheless, senescent $\mathrm{CD} 57^{+} \mathrm{CD} 8^{+} \mathrm{T}$ cells are able to secrete TNF- $\alpha$ and IFN- $\gamma$ upon encounter with antigen (15).

$\mathrm{CD} 8+\mathrm{CD} 28^{-} \mathrm{T}$ cells are end-stage cells that have lost the expression of CD28. Lin and colleagues showed that they had the lowest telomerase activity among memory and highly differentiated $\mathrm{CD}^{+} \mathrm{T}$ cell subsets. Consistent with this finding, those researchers also demonstrated that $\mathrm{CD} 8^{+} \mathrm{CD} 28^{-} \mathrm{T}$ cells had "the shortest mean telomere length" among the studied groups of memory T cells (16).

Prior studies suggest that the replicative capacity of $\mathrm{CD} 8^{+} \mathrm{CD} 28^{-} \mathrm{T}$ cells in response to antigen stimulation is significantly reduced and the telomere length is shorter in comparison with $\mathrm{CD} 8^{+} \mathrm{CD} 28^{+} \mathrm{T}$ cells (17). High percentages of $\mathrm{CD} 8^{+} \mathrm{CD} 28^{-} \mathrm{T}$ cells are related to reduced response to vaccination (18) and have been associated with mortality in a cohort of elderly Swedish (19).

A study in healthy Cubans showed an effect of gender in the dynamics of $\mathrm{T}$ cell subpopulations during aging. Although the proportion of late-differentiated $\mathrm{CD} 8^{+} \mathrm{CD} 28^{-}$and $\mathrm{CD} 8^{+} \mathrm{CD} 57^{+}$ $\mathrm{T}$ cells increased with age, it was only statistically significant in males. Cuban women preserve the proportion of $\mathrm{CD} 8^{+} \mathrm{CD} 28^{-}$ and $\mathrm{CD}^{+} \mathrm{CD}^{2} 7^{+} \mathrm{T}$ cells practically constant at all ages. Our group also reported other changes with age within the $\mathrm{CD} 8^{+} \mathrm{T}$ cell subset. In this occasion, an increased frequency of terminally differentiated $\mathrm{CD} 8^{+} \mathrm{CD} 45 \mathrm{RA}^{+} \mathrm{CD} 28^{-} \mathrm{T}$ cells was found in females as they aged, while males showed higher frequency of these cells from youth. By contrast, within $\mathrm{CD} 4^{+} \mathrm{T}$ lymphocytes, terminally differentiated $\mathrm{CD}^{+} \mathrm{CD} 45 \mathrm{RA}^{+} \mathrm{CD} 28^{-} \mathrm{T}$ cells showed an ageassociated increase in both sexes, though higher proportions were found in males (4).

The detection of differences concerning the structure and function of the immune system in males and females has been described $(20,21)$. In addition to hormones, genetic factors can determine the differences in the immune response between males and females. The fact that some genes in the $\mathrm{X}$ chromosome are involved in immunity has been addressed (21). It has also been proposed that estrogens improve humoral immunity, whereas androgens and progesterone have a tendency to hamper it (22).

Gender differences in the immune system have been evidenced also in epidemiological studies showing higher incidence of autoimmune diseases in females and higher rate of chronic inflammatory illness such as atherosclerosis-related diseases in males. Nevertheless, the interaction among hormones, genetics, inflammation, and immune system presents a complex scenario that must be more intensively studied (4).

The influence of gender in immunosenescence also appeared in the Berlin Aging Study II, which reported gender-related differences concerning the consequences of age and CMV infection 
on CD4 and CD8 T cells. This study reported that older men showed higher frequencies of late-differentiated $\mathrm{CD} 8{ }^{+} \mathrm{CD} 57^{+} \mathrm{T}$ cells and concluded that in elderly men, the "CMV-associated senescence of T cells" was more pronounced than in elderly women (23).

The Berlin study also showed a strong effect of CMV infection in the appearance of $\mathrm{CD} 45 \mathrm{RA}^{+} \mathrm{CCR} 7^{-} \mathrm{CD} 27^{-} \mathrm{CD} 28^{-}$terminally differentiated T cells (so-called TEMRA). They observed a significantly lower proportion of $\mathrm{CD} 4^{+} \mathrm{CD} 45 \mathrm{RA}^{+} \mathrm{CCR} 7^{-} \mathrm{CD} 27^{-} \mathrm{CD} 28^{-} \mathrm{T}$ cells in CMV-negative individuals than in CMV-positive individuals, regardless of gender and age. Concerning the frequency of $\mathrm{CD}^{+} \mathrm{T}$ cells, age was observed to have a significant influence, but here too, it was only significant in subjects with demonstrated CMV infection. Therefore, frequency of terminally differentiated $\mathrm{T}$ cells was significantly higher in CMV-positive elderly individuals than it was in CMV-negative elderly, notwithstanding gender (23).

Cytomegalovirus is a common herpes virus affecting the $60-90 \%$ of the global population. The prevalence of infected individuals increases with age. It is expected that $90 \%$ of individuals could be infected nearby the 90 decade of life in contrast with the evidence of $40-60 \%$ of individuals in the middle age population (24). The OCTO study reported that the prevalence of subjects with CMV-IgG antibodies in individuals older than 80 years was around $90 \%$, while in middle-aged individuals, it was relatively consistent at $67 \%$ (6). Interestingly, our group reported a high seroprevalence of CMV seropositivity greater than $80 \%$ in Cuban healthy population from young ages (4).

Persistent infection with viruses such us CMV can augment the accumulation of senescent $\mathrm{CD}^{+}$and $\mathrm{CD} 8^{+} \mathrm{T}$ cells, identified as $\mathrm{CD} 27^{-} \mathrm{CD} 28^{-} \mathrm{CD} 45 \mathrm{RA}^{+} \mathrm{KLRG}^{+}$and $\mathrm{CD}^{+} 7^{+}$, compared to age-matched seronegative individuals (25). The research in this area has been predominantly focused on $\mathrm{CD}^{+} \mathrm{T}$ cells, which display decreased naive populations and increased memory subset distribution consistent with a more memory/late effector cell profile. This is accompanied by changes in function such as reduced proliferative capacity, especially in $\mathrm{CD}_{57}{ }^{+} \mathrm{T}$ cells, and increased cytotoxic and secretory functions $(26,27)$.

However, changes in $\mathrm{T}$ cell subpopulations are also evident in $\mathrm{CD}^{+} \mathrm{T}$ lymphocytes. A recent work described the significant increment in the percentages of $\mathrm{CD} 4^{+} \mathrm{CD} 57^{+} \mathrm{T}$ cells in young CMV-positive individuals, compared with young CMV-negative individuals. They showed that CD4 ${ }^{+} \mathrm{T}$ cells that coexpress CD57 and CD154 are only present in CMV-positive subjects and are considered a very polyfunctional $\mathrm{CD}^{+}$subset (28). This group had previously revealed an increase in $\mathrm{CD} 8^{+} \mathrm{CD} 57^{+} \mathrm{T}$ cells in CMV-positive young subjects (29).

The CMV-IgG seropositivity was determined in healthy Cubans of all ages in a study conducted by Garcia and colleagues. The general seroprevalence of CMV seropositivity was $90 \%$. More than $90 \%$ of elderly individuals had antibodies against CMV, notwithstanding their gender. Nevertheless, young males (93.3\%) had higher seroprevalence than young females (73.6\%) (4).

In our analysis, the higher percentage of CD45RA ${ }^{+} \mathrm{CD} 28^{-} \mathrm{T}$ cells within the $\mathrm{CD}^{+}$and $\mathrm{CD}^{+}$subsets described in Cuban males, but not in females, during young ages can be explained by the differential effect of gender and age in the thymic output (4). Furthermore, since androgens and testosterone have higher association with severe thymus involution than female hormones, young males could have less protected immune system than females. This combined with exposure to high antigenic loads since early ages could have driven immunosenescence in young males $(4,30)$.

The thymic involution in elderly people induces a reduction of naive $\mathrm{T}$ cells in the periphery, regardless of CMV infection. Nonetheless, during persistent CMV infection, the memory $\mathrm{T}$ cells frequency is higher, possibly because of the latency of CMV, which exerts a persistent stimulation on the immune system in order to control the virus $(24,26)$. Additionally, CMV reactivation may occur more often in older people (31). From this point, an impairment of the immune system would hamper its capacity to control the CMV infection; therefore, a reactivation of the CMV would lead to a long-lasting antigen stimulation and accelerate the accumulation of CD28- $\mathrm{T}$ cells as well as the emergence of the phenomenon of immunosenescence, functioning as a closed loop (24).

\section{TREATMENT WITH PLATINUM-BASED CHEMOTHERAPY ENTAILS DIFFERENT PATTERNS OF TERMINALLY DIFFERENTIATED CD8 T CELLS IN NSCLC PATIENTS}

Around $70 \%$ of cancer-related deaths and $60 \%$ of new cancer diagnosis occur in patients older than 65 years (1). Moreover, as aging is a global phenomenon, a rapid increase in elderly with malignancies is expected (32).

A study in cancer patients (respiratory, digestive, reproductive, head, and neck) showed an expansion of $\mathrm{CD} 8^{+} \mathrm{CD} 28^{-} \mathrm{T}$ cells in heavy chemo-treated patients compared with healthy volunteers and treatment-naive patients (33). Another research in patients with various forms of lung cancer receiving chemotherapy reported higher proportions of $\mathrm{CD} 28^{-} \mathrm{CD} 57^{+}$cells, thereby highlighting the most pronounced changes in lung cancer patients with stage IV of the disease (34).

Recently, high proportions of $\mathrm{CD} 4{ }^{+} \mathrm{CD} 28^{-}$and $\mathrm{CD} 4{ }^{+} \mathrm{CD} 57^{+} \mathrm{T}$ cells have been reported in CMV-positive glioblastoma patients. Additionally, these researchers described short survival in glioblastoma patients with high proportions of $\mathrm{CD} 4{ }^{+} \mathrm{CD} 28^{-}$and $\mathrm{CD} 4{ }^{+} \mathrm{CD} 57^{+} \mathrm{CD} 28$ null $\mathrm{T}$ cells, thereby suggesting an association between those immunosenescence markers and survival in CMV-positive glioblastoma patients (35).

Our group evaluated the presence of the CD28 receptor on $\mathrm{CD}^{+}$and $\mathrm{CD}^{+} \mathrm{T}$ cells in a cohort of Cuban advanced NSCLC patients, before and after administration of first-line platinum-based chemotherapy. We found that the proportion of $\mathrm{CD} 4{ }^{+} \mathrm{CD} 28^{-} \mathrm{T}$ cells significantly increased in NSCLC patients after treatment with platinum-based chemotherapy, compared with healthy volunteers and with cancer patients without chemotherapy. Healthy volunteers and cancer patients without chemotherapy had low proportions of $\mathrm{CD}^{+} \mathrm{CD} 28^{-} \mathrm{T}$ cells. 
Cancer patients treated with standard front-line chemotherapy showed the highest proportions of $\mathrm{CD} 8^{+} \mathrm{CD} 28^{-} \mathrm{T}$ cells (36).

In addition, our group investigated the frequency of $\mathrm{CD}^{+}{ }^{+} \mathrm{CD} 57^{+} \mathrm{T}$ cells and CD45RA ${ }^{+} \mathrm{CD} 28^{-}$on $\mathrm{CD} 4^{+}$and $\mathrm{CD} 8^{+} \mathrm{T}$ cells in Cuban NSCLC patients after front-line platinum-based chemotherapy. We showed that the frequency of $\mathrm{CD} 8^{+} \mathrm{CD} 57^{+}$, $\mathrm{CD} 4{ }^{+} \mathrm{CD} 45^{+} \mathrm{CD} 28^{-}$, and $\mathrm{CD} 8^{+} \mathrm{CD} 45^{+} \mathrm{CD} 28^{-} \mathrm{T}$ cells remained unchanged, regardless of the presence of cancer itself or the chemotherapy treatment.

Based on the high prevalence of CMV infection in Cubans and on previous findings in healthy elderly (4), we hypothesized that notwithstanding cancer disease or chemotherapy, aging and possibly chronic CMV infection could be the main causes for the increase of CD45RA ${ }^{+} \mathrm{CD} 28^{-} \mathrm{T}$ cells (36). In our opinion, platinum-based chemotherapy probably causes only the increase of $\mathrm{CD} 28^{-} \mathrm{T}$ cell subpopulations within $\mathrm{CD} 4^{+}$and $\mathrm{CD} 8^{+}$subsets. Otherwise, changes in the frequency of $\mathrm{CD} 4^{+}$or $\mathrm{CD}^{+}{ }^{+} \mathrm{CD} 45 \mathrm{RA}^{+} \mathrm{CD} 28^{-}$and $\mathrm{CD} 57^{+} \mathrm{CD} 8^{+} \mathrm{T}$ cells seems not to be related with cancer disease or chemotherapy.

Although consensus about necessary chronic antigen stimulation, especially $\mathrm{CMV}$, to cause immunosenescence is under constant discussion, maintaining CMV reactivations under control requires a huge effort from the immune system. This virus could be responsible for the functional impairment of many cell types from innate and adaptive immune systems. Besides affecting the immunosurveillance, this virus could also contribute to the pathogenesis of some inflammatory diseases and even cancer (24).

\section{CD8 ${ }^{+}$CD28- $T$ CELLS AND CD4/CD8 RATIO AS PREDICTIVE BIOMARKERS OF EFFICACY OF THERAPEUTIC VACCINATION WITH THE EPIDERMAL GROWTH FACTOR (EGF)-BASED VACCINE CIMAvax-EGF}

The suppression induced by tumor disease and by standard therapies such as chemotherapy and radiation can influence detrimentally the immune system of cancer patients. Nowadays, the assessment of a patient's immune status represents a valuable tool for determine patients for undergoing immunotherapy $(37,38)$.

Biomarkers are becoming more necessary in order to select patients who could benefit from therapies, either in the initial phase of the disease or in advanced cancer stages. In such cases, the definition of personalized treatments in tumor disease could lead to an improvement of therapeutic success (39).

CIMAvax-EGF is a therapeutic cancer vaccine developed to generate specific humoral response against the EGF (40). More than 4,000 advanced NSCLC patients have been treated with the CIMAvax-EGF vaccine, which is safe and immunogenic and have proved its efficacy (41).

As previous results published by our Institute showed, a relation between the magnitude of specific anti-EGF antibody response and the clinical outcomes of vaccinated patients has been demonstrated when using CIMAvax-EGF as switch maintenance therapy after platinum-based first-line chemotherapy in NSCLC patients. Young patients showed the best clinical results $(42,43)$. These results suggest that the clinical benefit in CIMAvax-EGF vaccinated NSCLC patients goes together with the development of a good specific humoral response (36).

In a recent article, our group proposed the frequencies of $\mathrm{CD} 8^{+} \mathrm{CD} 28^{-} \mathrm{T}$ cells and the $\mathrm{CD} 4 / \mathrm{CD} 8$ ratio as possible predictive biomarkers for the CIMAvax-EGF efficacy. Consequently, NSCLC patients with a proportion of $\mathrm{CD} 8^{+} \mathrm{CD} 28^{-} \mathrm{T}$ cells of less than $24 \%$ and a CD4/CD8 ratio $>2$ determined after front-line standard chemotherapy and prior to vaccination with CIMAvax-EGF achieved a median survival superior by almost 20 months to that of vaccinated patients with more than $24 \%$ of CD $8^{+} \mathrm{CD} 28^{-} \mathrm{T}$ cells and a CD4/CD8 ratio $<2$. These findings emphasize the impact of the immune status on the clinical evolution of CIMAvax-EGF vaccinated NSCLC patients and validate the usefulness of latestage differentiated $\mathrm{CD} 8^{+} \mathrm{T}$ cells as predictive biomarkers for the CIMAvax-EGF efficacy (36).

As studies of the senescence of the immune system advance, it can be predicted that markers of the dynamics of lymphocytes and cytokines along individual's lifetime will be increasingly used as prognostic factors and treatment predictors in several diseases. In contrast to genetic markers, which are mainly endogenous individual traits, markers of immunosenescence evolve under extrinsic environmental influences, which obviously vary among diverse human groups. Thus, findings are difficult to extrapolate from country to country. For this reason, specific studies in diverse populations are needed to better asses the timelines of immunosenescence and the influence of chronic antigenic loads and gender. It has been predicted that different forms of immunotherapy will become part of the main therapeutic strategy in an increasing fraction of cancer patients in the near future. This scenario will make specific studies of immunosenescence mandatory.

\section{AUTHOR CONTRIBUTIONS}

DS, AL, and BG have overall responsibility for writing the paper.

\section{ACKNOWLEDGMENTS}

The authors thank all participating patients and their families, as well as staffs of all the institutions involved in the studies referred in this manuscript. The authors also thank Dr. Fernando Frias, Romy Acosta, and Mariana Mansur for the language corrections of the document.

\section{FUNDING}

This research was funded by the Center of Molecular Immunology and the National Ministry of Health. 


\section{REFERENCES}

1. Fulop T, Larbi A, Kotb R, de Angelis F, Pawelec G. Aging, immunity, and cancer. Discov Med (2011) 11(61):537-50.

2. Fulop T, Larbi A, Kotb R, Pawelec G. Immunology of aging and cancer development. Interdiscip Top Gerontol (2013) 38:38-48. doi:10.1159/000343599

3. Kern F, Khatamzas E, Surel I, Frommel C, Reinke P, Waldrop SL, et al. Distribution of human CMV-specific memory $\mathrm{T}$ cells among the CD8pos. subsets defined by CD57, CD27, and CD45 isoforms. Eur JImmunol (1999) 29(9):2908-15. doi:10.1002/ (SICI)1521-4141(199909)29:09<2908::AID-IMMU2908>3.0.CO;2-8

4. Garcia Verdecia B, Saavedra Hernandez D, Lorenzo-Luaces P, de Jesus Badia Alvarez T, Leonard Rupale I, Mazorra Herrera Z, et al. Immunosenescence and gender: a study in healthy Cubans. Immun Ageing (2013) 10(1):16. doi:10.1186/1742-4933-10-16

5. Chidrawar S, Khan N, Wei W, McLarnon A, Smith N, Nayak L, et al. Cytomegalovirus-seropositivity has a profound influence on the magnitude of major lymphoid subsets within healthy individuals. Clin Exp Immunol (2009) 155(3):423-32. doi:10.1111/j.1365-2249.2008.03785.x

6. Olsson J, Wikby A, Johansson B, Lofgren S, Nilsson BO, Ferguson FG. Age-related change in peripheral blood T-lymphocyte subpopulations and cytomegalovirus infection in the very old: the Swedish longitudinal OCTO immune study. Mech Ageing Dev (2000) 121(1-3):187-201. doi:10.1016/ S0047-6374(00)00210-4

7. Pawelec G. Hallmarks of human "immunosenescence": adaptation or dysregulation? Immun Ageing (2012) 9(1):15. doi:10.1186/1742-4933-9-15

8. Pera A, Campos C, Lopez N, Hassouneh F, Alonso C, Tarazona R, et al. Immunosenescence: implications for response to infection and vaccination in older people. Maturitas (2015) 82(1):50-5. doi:10.1016/j. maturitas.2015.05.004

9. Pawelec G. T-cell immunity in the aging human. Haematologica (2013) 99(5):795-7. doi:10.3324/haematol.2013.094383

10. Kouri V, Correa CB, Verdasquera D, Martinez PA, Alvarez A, Aleman Y, et al. Diagnosis and screening for cytomegalovirus infection in pregnant women in Cuba as prognostic markers of congenital infection in newborns: 2007-2008. Pediatr Infect DisJ(2010) 29(12):1105-10. doi:10.1097/INF.0b013e3181eb7388

11. Strioga M, Pasukoniene V, Characiejus D. CD8+ CD28- and CD8+ CD57+ $\mathrm{T}$ cells and their role in health and disease. Immunology (2011) 134(1):17-32. doi:10.1111/j.1365-2567.2011.03470.x

12. Brenchley JM, Karandikar NJ, Betts MR, Ambrozak DR, Hill BJ, Crotty LE, et al. Expression of CD57 defines replicative senescence and antigen-induced apoptotic death of CD8+ T cells. Blood (2003) 101(7):2711-20. doi:10.1182/ blood-2002-07-2103

13. Kared H, Martelli S, Ng TP, Pender SL, Larbi A. CD57 in human natural killer cells and T-lymphocytes. Cancer Immunol Immunother (2016) 65(4):441-52. doi:10.1007/s00262-016-1803-Z

14. Akbar AN, Henson SM. Are senescence and exhaustion intertwined or unrelated processes that compromise immunity? Nat Rev Immunol (2011) 11(4):289-95. doi:10.1038/nri2959

15. Le Priol Y, Puthier D, Lecureuil C, Combadiere C, Debre P, Nguyen C, et al. High cytotoxic and specific migratory potencies of senescent CD8+ CD57+ cells in HIV-infected and uninfected individuals. J Immunol (2006) 177(8):5145-54. doi:10.4049/jimmunol.177.8.5145

16. Lin J, Epel E, Cheon J, Kroenke C, Sinclair E, Bigos M, et al. Analyses and comparisons of telomerase activity and telomere length in human $\mathrm{T}$ and $\mathrm{B}$ cells: insights for epidemiology of telomere maintenance. J Immunol Methods (2010) 352(1-2):71-80. doi:10.1016/j.jim.2009.09.012

17. Effros RB. Replicative senescence: the final stage of memory $T$ cell differentiation? Curr HIV Res (2003) 1(2):153-65. doi:10.2174/1570162033485348

18. Goronzy JJ, Fulbright JW, Crowson CS, Poland GA, O'Fallon WM, Weyand $\mathrm{CM}$. Value of immunological markers in predicting responsiveness to influenza vaccination in elderly individuals. J Virol (2001) 75(24):12182-7. doi:10.1128/JVI.75.24.12182-12187.2001

19. Wikby A, Johansson B, Olsson J, Lofgren S, Nilsson BO, Ferguson F. Expansions of peripheral blood CD8 T-lymphocyte subpopulations and an association with cytomegalovirus seropositivity in the elderly: the Swedish NONA immune study. Exp Gerontol (2002) 37(2-3):445-53. doi:10.1016/ S0531-5565(01)00212-1
20. Grossman CJ. Regulation of the immune system by sex steroids. Endocr Rev (1984) 5(3):435-55. doi:10.1210/edrv-5-3-435

21. Caruso C, Accardi G, Virruso C, Candore G. Sex, gender and immunosenescence: a key to understand the different lifespan between men and women? Immun Ageing (2013) 10(1):20. doi:10.1186/1742-4933-10-20

22. Sakiani S, Olsen NJ, Kovacs WJ. Gonadal steroids and humoral immunity. Nat Rev Endocrinol (2013) 9(1):56-62. doi:10.1038/nrendo.2012.206

23. Di Benedetto S, Derhovanessian E, Steinhagen-Thiessen E, Goldeck D, Muller L, Pawelec G. Impact of age, sex and CMV-infection on peripheral T cell phenotypes: results from the Berlin BASE-II Study. Biogerontology (2015) 16(5):631-43. doi:10.1007/s10522-015-9563-2

24. Soderberg-Naucler C, Fornara O, Rahbar A. Cytomegalovirus driven immunosenescence - an immune phenotype with or without clinical impact? Mech Ageing Dev (2016) 158:3-13. doi:10.1016/j.mad.2016.06.005

25. Akbar AN, Henson SM, Lanna A. Senescence of T lymphocytes: implications for enhancing human immunity. Trends Immunol (2016) 37(12):866-76. doi:10.1016/j.it.2016.09.002

26. Pawelec G. Immunosenenescence: role of cytomegalovirus. Exp Gerontol (2014) 54:1-5. doi:10.1016/j.exger.2013.11.010

27. Terrazzini N, Kern F. Cell-mediated immunity to human CMV infection: a brief overview. F1000Prime Rep (2014) 6:28. doi:10.12703/P6-28

28. Pera A, Vasudev A, Tan C, Kared H, Solana R, Larbi A. CMV induces expansion of highly polyfunctional CD4+ T cell subset coexpressing CD57 and CD154. J Leukoc Biol (2016). doi:10.1189/jlb.4A0316-112R

29. Pera A, Campos C, Corona A, Sanchez-Correa B, Tarazona R, Larbi A, et al. CMV latent infection improves CD8+ T response to SEB due to expansion of polyfunctional CD57+ cells in young individuals. PLoS One (2014) 9(2):e88538. doi:10.1371/journal.pone.0088538

30. Hince M, Sakkal S, Vlahos K, Dudakov J, Boyd R, Chidgey A. The role of sex steroids and gonadectomy in the control of thymic involution. Cell Immunol (2008) 252(1-2):122-38. doi:10.1016/j.cellimm.2007.10.007

31. Stowe RP, Kozlova EV, Yetman DL, Walling DM, Goodwin JS, Glaser R. Chronic herpesvirus reactivation occurs in aging. Exp Gerontol (2007) 42(6):563-70. doi:10.1016/j.exger.2007.01.005

32. Falci C, Gianesin K, Sergi G, Giunco S, De Ronch I, Valpione S, et al. Immune senescence and cancer in elderly patients: results from an exploratory study. Exp Gerontol (2013) 48(12):1436-42. doi:10.1016/j. exger.2013.09.011

33. Chen IH, Lai YL, Wu CL, Chang YF, Chu CC, Tsai IF, et al. Immune impairment in patients with terminal cancers: influence of cancer treatments and cytomegalovirus infection. Cancer Immunol Immunother (2010) 59(2):323-34 doi:10.1007/s00262-009-0753-0

34. Onyema OO, Decoster L, Njemini R, Forti LN, Bautmans I, De Waele M, et al. Shifts in subsets of CD8+ T-cells as evidence of immunosenescence in patients with cancers affecting the lungs: an observational case-control study. BMC Cancer (2015) 15:1016. doi:10.1186/s12885-015-2013-3

35. Fornara O, Odeberg J, Wolmer Solberg N, Tammik C, Skarman P, Peredo I, et al. Poor survival in glioblastoma patients is associated with early signs of immunosenescence in the CD4 T-cell compartment after surgery. Oncoimmunology (2015) 4(9):e1036211. doi:10.1080/2162402X.2015.1036211

36. Saavedra D, Garcia B, Lorenzo-Luaces P, Gonzalez A, Popa X, Fuentes KP, et al. Biomarkers related to immunosenescence: relationships with therapy and survival in lung cancer patients. Cancer Immunol Immunother (2016) 65(1):37-45. doi:10.1007/s00262-015-1773-6

37. Gustafson MP, Lin Y, LaPlant B, Liwski CJ, Maas ML, League SC, et al. Immune monitoring using the predictive power of immune profiles. JImmunother Cancer (2013) 1:7. doi:10.1186/2051-1426-1-7

38. Chang S, Kohrt H, Maecker HT. Monitoring the immune competence of cancer patients to predict outcome. Cancer Immunol Immunother (2014) 63(7):713-9. doi:10.1007/s00262-014-1521-3

39. Berghella AM, Contasta I, Lattanzio R, Di Gregorio G, Campitelli I, Marino $\mathrm{S}$, et al. The role of gender-specific cytokine pathways as drug targets and gender-specific biomarkers in personalized cancer therapy. Curr Drug Targets (2016).

40. Rodriguez PC, Popa X, Martinez O, Mendoza S, Santiesteban E, Crespo T, et al. A phase III clinical trial of the epidermal growth factor vaccine CIMAvaxEGF as switch maintenance therapy in advanced non-small cell lung cancer patients. Clin Cancer Res (2016) 22(15):3782-90. doi:10.1158/1078-0432. CCR-15-0855 
41. Crombet Ramos T, Rodriguez PC, Neninger Vinageras E, Garcia Verdecia B, Lage Davila A. CIMAvax EGF (EGF-P64K) vaccine for the treatment of non-small-cell lung cancer. Expert Rev Vaccines (2015) 14(10):1303-11. doi:1 0.1586/14760584.2015.1079488

42. Garcia B, Neninger E, de la Torre A, Leonard I, Martinez R, Viada C, et al. Effective inhibition of the epidermal growth factor/epidermal growth factor receptor binding by anti-epidermal growth factor antibodies is related to better survival in advanced non-small-cell lung cancer patients treated with the epidermal growth factor cancer vaccine. Clin Cancer Res (2008) 14(3):840-6. doi:10.1158/1078-0432.CCR-07-1050

43. Neninger Vinageras E, de la Torre A, Osorio Rodriguez M, Catala Ferrer M, Bravo I, Mendoza del Pino M, et al. Phase II randomized controlled trial of an epidermal growth factor vaccine in advanced non-small-celllung cancer. J Clin Oncol(2008) 26(9):1452-8. doi:10.1200/ JCO.2007.11.5980

Conflict of Interest Statement: The authors declare that the research was conducted in the absence of any commercial or financial relationships that could be construed as a potential conflict of interest.

Copyright (C) 2017 Saavedra, Garcia and Lage. This is an open-access article distributed under the terms of the Creative Commons Attribution License (CC BY). The use, distribution or reproduction in other forums is permitted, provided the original author(s) or licensor are credited and that the original publication in this journal is cited, in accordance with accepted academic practice. No use, distribution or reproduction is permitted which does not comply with these terms. 